
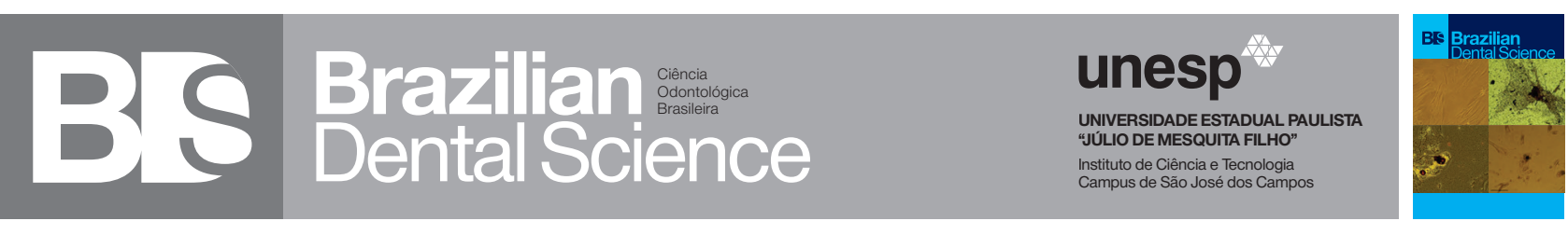

\title{
Evaluating of Cytotoxic Effects of Highly Esthetic Dental Composites
}

\author{
Avaliação dos efeitos citotóxicos de resinas compostas altamente estéticas
}

Numan AYDIN ${ }^{1}$, Serpil KARAOĞLANOĞLU1 ${ }^{1}$, Elif Aybala OKTAY ${ }^{1}$, Aysun Kılıç SÜLOĞLU²

1 - University of Health Sciences - Gulhane Faculty of Dentistry - Department of Restorative Dental Treatment - Ankara - Turkey.

2 - Hacettepe University - Faculty of Science Department of Biology - Ankara - Turkey.

\section{ABSTRACT}

Objective: Dental composites developed by using nanotechnology in the field of dentistry are widely used in the treatment of anterior and posterior teeth. This study aimed to investigate the cytotoxic effects of dental composites of different particle size on L929 mouse fibroblast cell line by extract test method in vitro. Material and Methods: Composite samples of $8 \times 2 \mathrm{~mm}$ diameter were prepared by polymerizing with led light device by using glass mod in a sterile cabinet. Composite samples of which surface areas were calculated according to ISO standards $\left(3 \mathrm{~cm}^{2}\right.$ / $\mathrm{ml}$ ), were incubated for 24 and 72 hours, at $37^{\circ} \mathrm{C}$. cell viability was assessed by 3-[4,5-dimethylthiazole-2yl]-2,5-diphenyltetrazolium bromide (MTT) assay and cell death was evaluated by the lactate dehydrogenase (LDH) leakage assay. Results: The 1:1 extracts of the composites at the end of 24 hours (except for nanoceramic composite) showed no toxic effect. When the cell viability results of the $1: 1$ extracts of the composite samples at the end of 72 hours were statistically analyzed, significant differences were found comparing to the control group ( $\mathrm{p}<0.05$ ). Conclusion: It was observed that the type and size of the filler were effective on the toxicity of the composites, and the composites containing Bis-GMA, TEGDMA, UDMA and Bis EMA monomers in their organic matrix showed acceptable cell viability (70\%) as specified by ISO. However, the composites with PEGDMA and BPA monomers in their organic matrix showed poor cell viability, which is below the acceptable level of $70 \%$, and were found to have a toxic effect.

\section{KEYWORDS}

Composite resin; Cytotoxicity; Cell viability; Mouse fibroblasts; MTT.

\section{RESUMO}

Objetivo: As resinas compostas desenvolvidas pela nanotecnologia no campo da odontologia são amplamente utilizadas no tratamento de dentes anteriores e posteriores. Este estudo teve como objetivo investigar os efeitos citotóxicos de resinas compostas de diferentes tamanhos de partículas na linha celular de fibroblastos de camundongos L929 pelo método de teste de extrato in vitro. Material e Métodos: Amostras compostas de $8 \times 2 \mathrm{~mm}$ de diâmetro foram preparadas por polimerização com dispositivo de luz led usando um molde de vidro em um gabinete estéril. Amostras de resinas cujas áreas de superfície foram calculadas de acordo com os padrões ISO $\left(3 \mathrm{~cm}^{2} / \mathrm{ml}\right)$, foram incubadas por 24 e 72 horas, a $37^{\circ} \mathrm{C}$. A viabilidade celular foi avaliada pelo ensaio de brometo de 3- [4,5-dimetiltiazol-2il] -2,5-difeniltetrazólio (MTT) e a morte celular foi avaliada pelo ensaio de infiltração de lactato desidrogenase (LDH). Resultados: Os extratos 1: 1 dos compósitos ao final de 24 horas (exceto o composto nanocerâmico) não apresentaram efeito tóxico. Quando os resultados de viabilidade celular dos extratos 1: 1 das amostras compostas ao final de 72 horas foram analisados, estatisticamente, foram encontradas diferenças significativas em relação ao grupo controle (p $<$ 0,05). Conclusão: Observou-se que o tipo e tamanho da carga foram eficazes na toxicidade dos compósitos, e os compósitos contendo os monômeros Bis-GMA, TEGDMA, UDMA e Bis EMA em sua matriz orgânica apresentaram viabilidade celular aceitável (70\%) como especificado pela ISO. No entanto, os compósitos com monômeros PEGDMA e BPA em sua matriz orgânica apresentaram baixa viabilidade celular, que está abaixo do nível aceitável de 70\%, e foram encontrados como tendo um efeito tóxico.

\section{PALAVRAS-CHAVE}

Resina composta; Citotoxicidade; Viabilidade celular; Fibroblastos de rato; MTT. 


\section{INTRODUCTION}

$\mathrm{R}$ estorative composites used in dental treatment are complex filling materials in natural human teeth color. They contain synthetic polymers, reinforcing fillers (ceramic particles), molecules triggering and regulating polymerization reaction that creates the crosslinked polymer matrix from the dimethacrylate resin monomers, also silane coupling agents that stick the fillers to the polymer matrix [1].

Since the resin composite materials first came into use, there have been significant advancements related to filler types, processing and morphology, probably more than developments in resin chemistry itself. As processing techniques have evolved over time, filler particle size has approximately decreased to $1 \mathrm{~nm}$, from microns [2].

Nanoparticles, originally developed in an effort to reply esthetic concerns are used today in some modern composites as nano-sized aggregates to improve mechanical properties, especially strength [3]. The parameters to classify composites have changed in time, but in general, the main focus has been on filler-size distribution, filler content or composition. Earlier composites categorized as "microfill" or "nanofill", containing only micro or nanoparticles, have replaced with a "hybrid" category and the new materials are commonly marketed as "nanohybrid". The new category refers to materials containing a fraction of both nano $(<100 \mathrm{~nm})$ and sub-micron particles ( $\leq 1 \mu \mathrm{m}$, typically averaging $0.5-1.0 \mu \mathrm{m}$ ) [2].

Nanohybrids could be expected to include a greater fraction of nanoparticles than "microhybrids" do. However, a categorization according to filler-size distribution does not show filler composition, morphology or specific filler properties (e.g. the use of PPF) [4,5].

The use of resin-based composites in restorative dental treatment is now omnipresent, and in the last several decades, restorations made with such materials have proved that they are satisfactory alternatives of amalgam to treat dental traumas and decays [6].

Although the popularity of dental composites has increased, there are concerns about the biocompatibility of these materials. It has been reported that the biocompatibility of the resin-based materials is correlated with the amount and structure of the organic substances released [7], and the monomers released from the resin matrix due to insufficient polymerization or dissolution could cause cytotoxic results over time $[8,9]$.

In the organic matrix of composites, BisGMA (bisphenol-A glycidyl dimethacrylate), TEGDMA (triethylene glycol dimethacrylate), BisEMA (ethoxylated bisphenol-A dimethacrylate), and UDMA (urethane dimethacrylate) monomers are more specifically used [10]. It is stated that one of these monomers, Bis-GMA, can increase the number of DNA strands and cause dosedependent genotoxicity [11]. Low molecular weight monomer TEGDMA, on the other hand, is reported to reduce the level of glutathione (GSH), protecting cells from the damage caused by reactive oxygen radicals (ROS) $[12,13]$.

The aim of our study was to examine the in vitro cytotoxic effects of highly esthetic supra-nano, submicron hybrid, nanohybrid, nano-ceramic and microhybrid composites of different particle size on L929 mouse fibroblast cells by the extract test method employing MTT and LDH assays. The null hypothesis of our study was that highly esthetic composites would not have cytotoxic effects on L929 mouse fibroblast cells.

\section{MATERIAL AND METHOD} medium

1. Preparation of filler samples and

In the study, composite materials; Ceram.x Duo E2 (Dentsply Sirona, Germany), IPS Empress DirectA2 enamel (IvoclarVivadent, Liechtenstein), Estelite Asteria A2B body (Tokuyama, Japan), Brillant EverGlow A2/B2 (Coltene, Switzerland), Essentia Light Enamel (GC, Tokyo, Japan), Harmonize A2 enamel (Kerr, USA) Amaris NT (Voco, Germany) and Filtek Ultimate A2 enamel (3M ESPE, USA) were used (Table 1). Composite samples of $8 \times 2 \mathrm{~mm}$ diameter, prepared by using a glass mod in a sterile cabinet, were placed in sterile tubes. The composites were polymerized for $20 \mathrm{sec}$. using a DTE LUX E (Germany, 1000 $\mathrm{mW} / \mathrm{cm}^{2}$, tip diameter $8 \mathrm{~mm}$ ) led light device. Cylinder composite samples of which surface areas were calculated according to ISO 1099312: 2012 standards [16] (3 cm2 / ml) (n: 5), 
were incubated in $2.5 \mathrm{ml}$ serum-free Dulbecco's modified Eagle medium (DMEM) (HyClone Laboratories, Inc., Logan, UT, USA) medium (control group in serum-free medium) for 24 and 72 hours, at $37^{\circ} \mathrm{C}$, in an incubator with $5 \% \mathrm{CO}_{2}$. The outer surfaces of the tubes were covered with aluminum foil so that the composite samples kept in the serum-free DMEM medium were not exposed to light. The extracts of composite samples filtered after 24 and 72 hours were diluted with DMEM medium (1:1 and 1:2) and used in cytotoxicity experiments.

Table 1 - Highly esthetic composites and their components

\begin{tabular}{|c|c|c|c|c|c|}
\hline \multirow{2}{*}{ Material } & \multirow{2}{*}{ Type } & \multicolumn{2}{|c|}{ Composition } & \multirow{2}{*}{$\begin{array}{l}\text { Filler } \\
\text { content } \\
\text { (w/w) }\end{array}$} & \multirow{2}{*}{$\begin{array}{c}\text { Lot } \\
\text { Number }\end{array}$} \\
\hline & & Matrix & Filler & & \\
\hline $\begin{array}{l}\text { Ips Empress } \\
\text { Direct } \\
\text { (Ivoclar Vivadent, } \\
\text { Lihtenştayn) }\end{array}$ & Nanohybrid & $\begin{array}{l}\text { Bis-GMA } \\
\text { TCDDMA } \\
\text { UDMA }\end{array}$ & $\begin{array}{l}\text { Barium glass filler } \\
0.4 \mu \mathrm{m} \\
\text { Prepolymer } 1-10 \mu \mathrm{m} \\
\text { Ytterbium trifluori- } \\
\text { de } 100 \mathrm{~nm}\end{array}$ & $\begin{array}{c}77.5-79 \\
/ 60.5\end{array}$ & W93164 \\
\hline $\begin{array}{l}\text { Harmonize } \\
\text { (Keer, ABD) }\end{array}$ & Nanohybrid & $\begin{array}{l}\text { BisGMA } \\
\text { Bis EMA } \\
\text { TEGDMA }\end{array}$ & $\begin{array}{c}\text { Barium glass fillers } \\
5-400 \mathrm{~nm}\end{array}$ & $81 / 64.5$ & 6643739 \\
\hline $\begin{array}{c}\text { Estelite Asteria } \\
\text { (Tokuyama, Tokyo, } \\
\text { Japan) }\end{array}$ & $\begin{array}{l}\text { Supra-nano } \\
\text { spherical }\end{array}$ & $\begin{array}{l}\text { Bis-GMA } \\
\text { Bis-MPEPP } \\
\text { TEGDMA } \\
\text { UDMA }\end{array}$ & $\begin{array}{l}\text { Supra-nano } \\
\text { Spherical filler, } \\
\text { Composite filler } \\
\text { (200 nm spherical } \\
\text { SiO2-Zr02) }\end{array}$ & $82 / 71$ & W114 \\
\hline $\begin{array}{c}\text { Brilliant } \\
\text { EverGlow } \\
\text { (Coltene/Whale- } \\
\text { dent, Switzerland) }\end{array}$ & $\begin{array}{l}\text { Submicron } \\
\text { hybrid }\end{array}$ & $\begin{array}{l}\text { Bis-GMA } \\
\text { TEGDMA }\end{array}$ & $\begin{array}{c}\text { Dental glass } 0.02- \\
1,5 \text { um, Amorf silica, } \\
\text { Zinc oxide }\end{array}$ & $74 / 56$ & 100372 \\
\hline $\begin{array}{c}\text { Essentia } \\
\text { (GC Corporation, } \\
\text { Tokyo, Japan) }\end{array}$ & Microhybrid & $\begin{array}{l}\text { Bis-GMA } \\
\text { Bis-MPEPP } \\
\text { TEGDMA } \\
\text { UDMA }\end{array}$ & $\begin{array}{l}\text { Barium glass } 300 \\
\mathrm{~nm}, \\
\text { Füme silica } 16 \mathrm{~nm} \\
\text { (Prepolimerize } \\
\text { fillers } 10 \mu \mathrm{m} \text { ) }\end{array}$ & $81 / 65$ & 1704051 \\
\hline $\begin{array}{c}\text { Amaris } \\
\text { (Voco, Cuxhaven,- } \\
\text { Germany) }\end{array}$ & Microhybrid & $\begin{array}{c}\text { Bis-GMA } \\
\text { TEGDMA } \\
\text { UDMA }\end{array}$ & $\begin{array}{c}\text { Glass ceramic } \\
0.7 \mu \mathrm{m}\end{array}$ & $80 / 64$ & 1815363 \\
\hline $\begin{array}{l}\text { Filtek Ultimate } \\
\text { (3MESPE St. Paul, } \\
\text { USA) }\end{array}$ & Nanofil & $\begin{array}{l}\text { Bis-GMA } \\
\text { UDMA } \\
\text { TEGDMA } \\
\text { PEGDMA } \\
\text { Bis-EMA }\end{array}$ & $\begin{array}{l}\text { Silica filler } 20 \mathrm{~nm} \\
\text { zirkonyum ve } \\
4-11 \mathrm{~nm}\end{array}$ & $78.5 / 63.3$ & N717544 \\
\hline $\begin{array}{l}\text { Ceram.x Duo } \\
\text { (Dentsply Sirona, } \\
\text { Almanya) }\end{array}$ & $\begin{array}{l}\text { Nano- } \\
\text { ceramic }\end{array}$ & $\begin{array}{l}\text { Metha- } \\
\text { crylate } \\
\text { modified } \\
\text { polysilo- } \\
\text { xane, } \\
\text { metakri- } \\
\text { latlar }\end{array}$ & $\begin{array}{l}\text { Barium glass, } \\
\text { ytterbium flüoride } \\
\text { inorganic fillers } \\
0.1-3.0 \mu \mathrm{m} \text {. }\end{array}$ & $\begin{array}{l}77-79 \\
159-61\end{array}$ & 1804000829 \\
\hline
\end{tabular}

*BisGMA: Bisfenol diglisidilmetakrilat, BisEMA: bisfenoletilmetakrilat, UDMA: üretan dimetakrilat, PEGDMA: polietilen glikol dimethacrylate, TEGDMA: trietilenglikol dimethacrylate; Bis-MEPP: 2,2-bis (4-methacryloxypolyethoxyphenyl) propane

\section{Cell Culture}

The L929 mouse fibroblast cell line used in the study was removed from storage at -196 ${ }^{\circ} \mathrm{C}$ and dissolved in a water bath at $37{ }^{\circ} \mathrm{C}$ and centrifuged. The cells were routinely maintained in DMEM supplemented with $10 \%$ fetal bovine serum (PAA Laboratories, Linz, Austria) at $37^{\circ} \mathrm{C}$ and $5 \% \mathrm{CO}_{2}$ in a humidified incubator. Once the cells reached sufficient density, the cell suspension was prepared as described in ISO 10993-5: 2009 $\left(1^{\times} 10^{5}\right.$ cells $\left./ \mathrm{ml}\right)$ [14] by calculating the cell number of the desired density for 96-well cell culture plate using DMEM medium containing $10 \%$ FBS and $1 \%$ antibiotic. This cell suspension was divided into 96 well cell culture plate (100 $\mu \mathrm{l} /$ well) and incubated for 24 hours in a $5 \% \mathrm{CO}_{2}$ incubator. At the end of this period, DMEM was removed and the media of two different dilutions, in which the filling materials were kept, were divided into wells $(100 \mu \mathrm{l} /$ well $)$ and incubated for 24 hours in a $5 \% \mathrm{CO}_{2}$ incubator. Then, the MTT assay was applied.

\section{Cytotoxicity Test}

MTT ([3- (4,5-dimethylthiazol-2-yl) -2,5-diphentyltetrazolium bromide], Sigma, USA) was mixed with PBS, homogenized and MTT solution with final concentration of $5 \mathrm{mg}$ / $\mathrm{ml}$ was prepared. The secreted media in 96well cell culture plate that were incubated for 24 hours was removed after incubation, then $100 \mu \mathrm{l} /$ well DMEM medium and $13 \mu \mathrm{l}$ /well MTT solution was filled in clusters and they were incubated at $37^{\circ} \mathrm{C}$ in a dark environment for 4 hours. After incubation, the MTT solution was removed from the medium by aspiration. $100 \mu \mathrm{l}$ /well AmmoniaDMSO (5:100) mixture was placed in 96-well cell culture plate and the absorbance was read at $550 \mathrm{~nm}$ at the optical reader (BIO-TEK $\mu$ Quant, BIO-TEK Instruments, Inc, USA) then, compared with the control wells. Experiments have been triplicated and surviving cell \% was defined as the treatment group/control group (control group assumed as $100 \%$ survival).

\section{assay}

4. Lactate dehydrogenase (LDH) leakage

Lactate dehydrogenase (LDH) cytotoxicity assay was performed by following the instructions in the commercial kit. In brief, L929 cells were cultured in 96-well cell culture plate at a 
density of $1^{\times} 10^{4}$ cells/well and incubated in a humidified atmosphere with $5 \% \mathrm{CO}_{2}$ at $37^{\circ} \mathrm{C}$ for $24 \mathrm{~h}$. After removing culture media, cells were exposed to extract materials. In order to calculate the percentage of cytotoxicity in this assay, for max LDH levels a high control group was required (non-treated cells were exposed to lysis solution). Existing culture media were collected and centrifuged at $600 \mathrm{~g}$ for $10 \mathrm{~min}$. Then 100 $\mu \mathrm{l}$ of LDH reaction mix were added onto $10 \mu \mathrm{l}$ supernatant of sample and incubated for $30 \mathrm{~min}$ at room temperature. Absorbance levels of samples were read at $450 \mathrm{~nm}$ and $650 \mathrm{~nm}$ reference wavelength in microplate spectrophotometer (BIO-TEK $\mu$ Quant, BIO-TEK Instruments, Inc, USA). Experiments were carried out for three times. To calculate the percentage of cytotoxicity the below formula was used:

Absorbance of sample- absorbance of control / Absorbance of high control - absorbance of control x100.

\section{Statistical Analysis}

Statistical data analysis was performed using the SPSS 22.0 statistical program (SPSS Inc., Chicago, IL, USA). Cell viability values of the $1: 1$ and $1: 2$ diluted extracts of the composite materials at the end of 72 hours were evaluated by using one-way analysis of variance (ANOVA) and Tukey multiple comparison test $(\mathrm{p}<0.05)$.

\section{RESULTS}

In the evaluation, it was found that $1: 1$ and $1: 2$ extracts of composite samples at the end of 24 hours did not show toxic effects (except for nanoceramic composite Ceram.x Dou). However, when the cell viability results of $1: 1$ composite extract at the end of 72 hours were analyzed, significant differences were found in comparison to the control group ( $\mathrm{p}<0.05)$. In this analysis, supra-nano composite (Estelite Asteria) and sub-micron hybrid composite (Brilliant EverGlow) showed the highest cell viability, while the nano-ceramic composite (Ceram.x Dou) showed the lowest (Fig. 1).
When the cell viability values of $1: 1$ extracts of composite samples were evaluated according to control group (100\%), the composite materials were listed respectively as Estelite Asteria> Brilliant EverGlow $>$ Harmonize $>$ Amaris $>$ Essentia $>$ IPS Empress Direct $>$ Filtek Ultimate $>$ Ceram.x Dou (Table 2).

When the LDH test results of the 1:1 extracts of the composite samples at the end of 72 hours were examined, the composite groups (except for the nano-ceramic composite) did not have any toxic effects, and according to the LDH test, $32 \%$ (Fig. 2) of the cell deaths in the nanoceramic composite (Ceram.x Dou) was observed to be caused by cell membrane breakdown (necrosis).

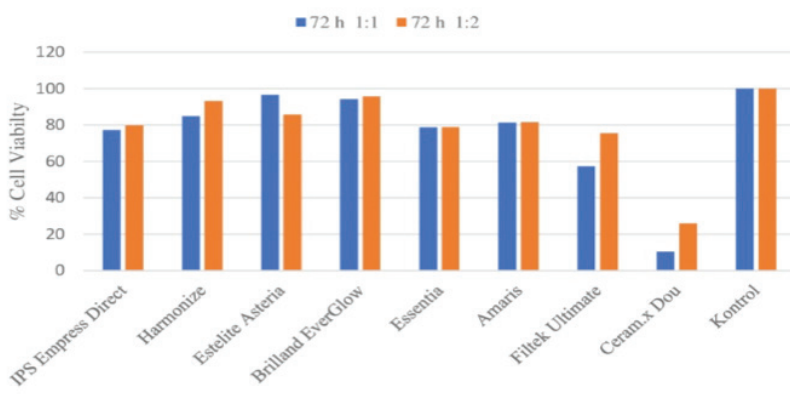

Figure 1 - MTT assay results of the extracts of composites at the of $72 \mathrm{~h}(\%)$

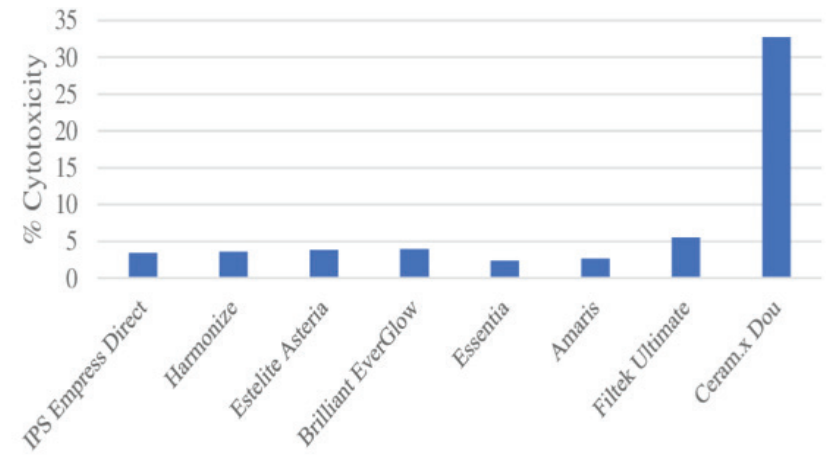

Figure 2 - LDH leakage assoy of the 1:1 composite extracts on the membrane integrity of the L929 cells after $72 \mathrm{~h}$ of incubation. 
Table 2 - Highly esthetic composites and their components

\begin{tabular}{|c|c|c|c|c|}
\hline Composites & $\begin{array}{c}\text { Cell } \\
\text { absorbance } \\
\text { value(1:1) }\end{array}$ & $\begin{array}{c}\text { Cell } \\
\text { Viability (1:1) } \\
\text { (\%) }\end{array}$ & $\begin{array}{c}\text { Cell } \\
\text { absorbance } \\
\text { value(1:2) }\end{array}$ & $\begin{array}{c}\text { Cell } \\
\text { Viability (1:2) } \\
(\%)\end{array}$ \\
\hline $\begin{array}{l}\text { IPS Empress } \\
\text { Direct }\end{array}$ & $1.09 \pm 0.15^{\mathrm{a}}$ & 77.4 & $0.95 \pm 0.14^{\mathrm{b}}$ & 79.8 \\
\hline Harmonize & $1.19 \pm 0.17^{\mathrm{ab}}$ & 84.9 & $1.11 \pm 0.2^{1 a b}$ & 93.2 \\
\hline Estelite Asteria & $1.36 \pm 0.15^{b, c}$ & 96.6 & $1.01 \pm 0.14^{a b}$ & 85.7 \\
\hline Brilliant EverGlow & $1.32 \pm 0.21^{1-c}$ & 94.2 & $1.14 \pm 0.38^{a}$ & 95.7 \\
\hline Essentia & $1.11 \pm 0.36^{\mathrm{a}}$ & 78.8 & $0.94 \pm 0.19^{\circ}$ & 78.9 \\
\hline Amaris & $1.14 \pm 0.07^{\mathrm{ab}}$ & 81.3 & $0.96 \pm 0.2^{\text {ab }}$ & 80.6 \\
\hline Filtek Ultimate & $0.80 \pm 0.24^{d}$ & 57.3 & $0.90 \pm 0.29^{b}$ & 75.6 \\
\hline Ceram.xDou & $0.15 \pm 0.03^{e}$ & 10.6 & $0.31 \pm 0.15^{c}$ & 26.1 \\
\hline Control & $1.41 \pm 0.24^{c}$ & 100 & $1.19 \pm 0.32^{\mathrm{a}}$ & 100 \\
\hline
\end{tabular}

* a-e shows the difference between the significance levels of the lines. $p<0.05$

\section{DISCUSSION}

Although several test methods are employed in research evaluating the biocompatibility of restorative materials used in dentistry, animal experiments and cell culture tests are often preferred [15]. Cell culture assays are better standardized and reproducible, also compared to animal experiments the application is easier, less time-consuming and economic that's why they are more commonly used.

The International Standards Organization (ISO) 10993-12: 2012 proposed several cell culture test models to assess the cytotoxicity of dental materials [16]. These are direct contact (direct method), indirect contact with a barrier (indirect method) and (extract method) in which extracts from biomaterials are added onto cells. Lim et al. [17] in their study comparing the in vitro test models used in the evaluation of the cytotoxicity of composite resins, suggested preferring the extract test method because of its higher sensitivity if a single test model is used.

In cell culture assays, the L929 mouse fibroblast cell line is the most widely used cell line for the evaluation of cytotoxicity of dental materials [18]. The major advantages of L929 cell lines are that it is easy to use, contains a single type of cells and have successful toxic responses [18]. In this in vitro study, the cytotoxic effects of 8 different highly esthetic light-curing composites on L-929 mouse fibroblast cells were examined by extract test method employing MTT assay according to ISO 10993-12: 2012 standards [16].

It is stated that the degree of polymerization of composite materials used in restorative dentistry is effective on toxicity [19] and that the oxygen inhibition layer formed on the surface of the composites after polymerization increases monomer release [20]. Caughman et al. [21] in their study evaluating the cytotoxicity of composites stated that the curing time decreases the cytotoxicity by increasing the monomer transformation. Van Landuyt et al. [22] however, reported that no correlation could be found between the oxygen inhibition layer, formed after the polymerization under glass cover during the preparation of the composite samples, and the monomer release. In our study, in order to increase the polymerization degree of the composite materials, the materials were placed under a $1 \mathrm{~mm}$ glass coverslip and polymerized for 20 seconds with led light device.

In a study conducted on human gingival fibroblasts and L929 mouse fibroblasts to evaluate the toxicity of nanofilled and nanohybrid composite resins, Schubert et al. [23] reported that composite extracts at the end of 72 hours caused a statistically significant decrease in cell viability. In their study on the toxicity of dental packable and non-packable composite materials on L-929 mouse fibroblasts, Franz et al. [24] concluded that composite materials caused a statistically significant reduction in the number of cells compared to the control group. In a study by Cao et al. [19] comparing the dental composite toxicity on L-929 mouse fibroblasts (by extract test method), the number of cells did not show a statistically significant change compared to the control group. In our study, although the 1:1 extracts of highly esthetic supra-nano, sub-micron hybrid, nanohybrid, nano-ceramic and microhybrid composites at the end of 72 hours caused a decrease in the cell viability comparing to the control group, only the nanofilled (Filtek Ultimate) and nano- 
ceramic (Ceram.x Dou) composites were found to be below the acceptable (70\%) cell viability at ISO standards. As a result of the toxic effect of some of the highly esthetic composites, our null hypothesis was rejected.

The filler content of the composite resins, particle size and the distribution of the particles affect their mechanical properties. Thus, producers increased the proportion of filler of composites for high esthetics and good clinical performance, while reducing the size of filler particles $[25,26]$. In their study, Ergun et al. [27] stated that the composite with the maximum filler proportion (Grandio Caps, 87\%) showed the highest cell viability and this could be related to the fact that a high filler proportion decrease the amount of soluble resin. In our study, although supra-nano composite (Estelite Asteria) with the highest filler content (82\%) showed the highest cell viability, the difference between the supra-nano composite and the submicron hybrid composite (Brilliant EverGlow) with the lowest filler proportion (74\%) was not statistically significant. When the composites containing similar inorganic fillers in the same proportion were compared, it was observed that the extracts of nanohybrid composite (IPS Empres Direct) did not have toxic effects at the end of 72 hours, while the nano-ceramic composite (Ceram.x Dou) had.

Both the resin content and the degree of monomer conversion of the composites were considered to be effective on cytotoxicity [20]. Monomers such as Bisphenol-A glycidylmethacrylate (Bis-GMA), triethyleneglycol dimethacrylate (TEGDMA), urethane dimethacrylate (UDMA), released from the structure of composites have been shown to be cytotoxic in many studies [28,29]. The organic matrix of the composite materials used in our study includes monomers such as BisGMA, Bis-EMA, Bis-MEPP, PEGDMA and UDMA. Compared to the control group, no significant difference was found between the supra-nano composite (Estelite Asteria) containing Bis-GMA, Bis-EMA, Bis-MEPP ve UDMA monomers in its organic matrix and submicron hybrid composite
(Brilliant EverGlow) containing the Bis-GMA and TEGDMA, in terms of cell viability of the extracts after 72 hours. However, the nanofilled composite (Filtek Ultimate), which contains all of the BisGMA, TEGDMA, Bis-EMA, PEGDMA and UDMA monomers in its organic matrix showed a 57.3\% cell viability, while nano-ceramic composite (Ceram.x Dou) containing organically modified ceramic and methacrylates showed only $10.6 \%$ cell viability (table 2 ).

In their study examining the toxicity of dental materials on L929 fibroblasts Franz et al. [30] reported that Filtek Supreme showed $65 \%$ cell viability and that its toxic effect could be associated with polyethylene glycol dimethacrylate (PEGDMA) included in the organic matrix of the composite. In their study on the effects of dental composites on gingival cells, Jerg et al. [31] also stated that the toxic effect of Filtek Supreme XTE could be related to PEGDMA. In our study, the nanofilled composite (Filtek Ultimate) showed a cell viability of 57.3\%, similar to the results of Franz et al. [30] and it is also considered to be associated with PEGDMA monomer in its structure.

Polydorou et al. [32] in their study on the long-term monomer release of modern dental composites (Filtek Supreme XT, Ceram X, and Clearfil Core), reported that the composite containing organically modified ceramic (Ceram $\mathrm{X}$ ) caused less monomer release. They also observed that BisGMA, TEGDMA, and Bisphenol A (BPA) monomers were released from the organically modified ceramic composite at different rates. In similar studies in the literature, it has been stated that the organically modified ceramic composite (Ceram X) has no significant toxic effect on the cells $[31,33,34]$.

However, in our study, the 1:1 extracts of the nano-ceramic composite at the end of 24 and 72 hours (Ceram.x Dou) showed 13.6\% and $10.6 \%$ cell viability. When the LDH test results of this composite were examined, it was found that $32 \%$ of cell deaths were due to the breakdown of the cell membrane (necrosis). When the studies in the literature are examined, it is considered 
that the toxic effect of nano-ceramic composite could be caused by Bisphenol A in its structure.

In vitro studies on toxicity reported that monomer release occurred for up to 24 hours following the polymerization and the cytotoxic effect continued, but the release of monomers after 24 hours was negligible [35]. In a study by Schubert et al. [23] investigating the toxic effects of nanofilled and nanohybrid composites on L-929 mouse fibroblasts less cell viability was observed after 48 and 72 hours, while no toxic effects occurred during the first 24 hours. In our study, no toxic effect was observed in the extracts of the composite samples (except Ceram.x Dou) at the end of 24 hours, while at the end of 72 hours the extracts showed a decrease in cell viability compared to the control group. Our data show that the release of cytotoxic agents continues after the first 24 hours following the polymerization of the composite material.

Among the limitations of this in vitro study, choosing only one cell line and a single test model for the evaluation of cytotoxic effects of composites could be stated. In this case, L-929 mouse fibroblasts serve only the general and preliminary evaluation purposes. In addition to differences in cell lines, indirect contact tests and different test models using primary cells may also lead to uncertainty and variability in cytotoxic responses. In further studies, working with more types of cell lines and more tests to verify the cytotoxic properties of composite materials may be considered.

\section{CONCLUSION}

In this study investigating the toxic effects of highly esthetic composites on L929 mouse fibroblast cells;

1. The supra-nano composite (Estelite Asteria) and submicron hybrid composite (Brilliant EverGlow) showed the highest cell viability, while the nanoceramic composite (Ceram.x Dou) showed the least cell viability;

2. The composites containing Bis-GMA, TEGDMA, UDMA and Bis EMA monomers in their organic matrix show acceptable cell viability as specified by ISO (70\%), while the composites with PEGDMA and BPA monomers were found to be below the standards;

3. Regarding the clinical use, in order to fully understand the effects of highly esthetic composites on patients, further study with different cell types and test models is considered to be beneficial.

\section{Conflict of interest}

The authors did not have any commercial interest in any of the materials used in this study.

*This study "The 1st International Congress of Dental and Oral Infection 7-9 September 2018 Sakarya /Turkey" is presented as oral presentation.

\section{REFERENCES}

1. Ferracane JL.Current trends in dental composites. Crit Rev Oral Biol Med. 1995;6(4):302-18.

2. Ferracane JL. Resin composite-state of the art. Dent Mater.2011 Jan;27(1):2938. doi:10.1016/j.dental.2010.10.020. Epub2010 Nov 18.

3. Curtis AR, Palin WM, Fleming GJ, Shortall ACC, Marquis PM. The mechanical properties of nanofilled resin-basedcomposites: the impact of dry and wet cyclic pre-loading onbi-axial flexure strength. Dent Mater.2009 Feb;25(2):18897.doi: 10.1016/j.dental.2008.06.003. Epub2008 Jul 24.

4. Kim KH, Ong JL, Okuno 0 . The effect of filler loading andmorphology on the mechanical properties of contemporarycomposites.JProsthet Dent. 2002 Jun;87(6):642-9.

5. Scougall-Vilchis RJ, Hotta Y, Hotta M, Idono T, Yamamoto K. Examination of composite resins with electron microscopy, microhardness tester and energy dispersive x-raymicroanalyzer.Dent Mater J.2009 Jan;28(1):102-12.

6. Sunnegardh-Gronberg K, Van Dijken JW, Funegard U, Lindberg A, Nilsson M. Selection of dental materials and longevity of replaced restorations in Public Dental Health clinics in northern Sweden. J Dent. 2009 Sep;37(9):673-8. doi: 10.1016/j.jdent2009.04.010. Epub 2009 May 4.

7. Eckhardt A, Harorli T,Limtanyakul J, Hiller KA, Bos IC, Bolay C, et al. Inhibition of cytokine and surface antigenexpression in LPS-stimulated murine macrophages bytriethylene glycol dimethacrylate. Biomaterials. 2009 Mar;30(9):1665-74. doi:10.1016/j.biomaterials.2008.09.024. Epub 2009 Jan 21.

8. Geurtsen W.Biocompatibility of resin-modified filling materials. CritRev Oral Biol Med. 2000;11(3):333-55.

9. Ferracane J.Elution of leachable components from composites. J Oral Rehabil. 1994 Jul;21(4):441-52.

10. Fugolin APP,Pfeifer CS. New Resins for Dental Composites. J Dent Res. 2017 Sep;96(10):1085-1091. doi: 10.1177/0022034517720658. Epub 2017 Jul 21. 
11. LiYC, Kuan YH, Huang FM, Chang YC. The role of DNA damage and caspase activation in cytotoxicity andgenotoxicity of macrophages induced by bisphenol-A-glycidyldimethacrylate. Int Endod J.2012 Jun;45(6):499-507. doi: 10.111//.1365-2591.2011.02001.x. Epub 2012 Jan 14.

12. Lee DH, Lim BS, Lee YK, Ahn SJ, Yang HC. Involvement ofoxidative stress in mutagenicity and apoptosis caused by dental resin monomers in cell cultures. DentMater. 2006 Dec;22(12):1086-92. Epub 2006 Jan 10

13. SchweikIH,Spagnuolo G, Schmalz G. Genetic and cellular toxicology of dental resin monomers. J Dent Res. 2006 0ct;85(10):870-7.

14. IS0 10993-5:2009. Biological evaluation of medical devices. Part5: Tests for in vitro cytotoxicity.2009

15. Murray PE, García Godoy C, García Godoy F. How is the biocompatibilty of dental biomaterials evaluated? Med Oral Patol Oral Cir Bucal.2007 May 1;12(3):E258-66.

16. IS0 10993-12:2012. Biological evaluation of medical devices. Part 12: Sample preparation and reference materials, 2012

17. Lim SM, Yap A, Loo C, Ng J, Goh CY,Hong C, etal. Comparison of cytotoxicity test models for evaluating resin-based composites. Hum Exp Toxicol. 2017 Apr;36(4):339-348. doi:10.1177/0960327116650007. Epub 2016 May 18

18. Saw TY,Cao T, Yap AUJ, Lee Ng MM. Tooth slice organ culture and established cell line culture models for cytotoxicity assessment of dental materials. Toxico In Vitro. 2005Feb;19(1):145-54.

19. Cao T,Saw TY,Heng BC, Liu H, Yap AU,Ng ML Comparison of different test models for the assessment of cytotoxicity of composite resins. J Appl Toxicol. 2005 Mar-Apr;25(2):101-8.

20. Pulgar R, Olea-Serrano MF, Novillo-Fertrell A, Rivas A, Pazos P,Pedraza V. et al. Determination of bisphenol $A$ and related aromatic compounds released from bis-GMA-based composites and sealants by high performance liquid chromatography. Environ Health Perspect. 2000 Jan;108(1):21-7.

21. Caughman WF, Caughman GB, ShiflettRA, Rueggeberg F, Schuster GS Correlation of cytotoxicity, filler loading and curing time of dental composites. Biomaterials. 19910ct;2(8):737-40.

22. Van Landuyt KL, Nawrot T, Geebelen B, De Munck J, Snauwaert J, Yoshihara K, et al. How much do resin-based dental materials release? A meta-analytical approach.Dent Mater.2011 Aug;27(8):723-47.doi: 10.1016/j.dental.2011.05.001. Epub 2011Jun 12.
23. Schubert A, Ziegler C,Bernhard A, Bürgers R, Miosge N. Cytotoxic effects to mouse and human gingival fibroblasts of a nanohybrid ormocer versus dimethacrylate-based composites. Clin Oral Investig. 2019 Jan;23(1):133-139. doi: 10.1007/s00784-018-2419-9. Epub2018 Mar 30.

24. Franz A, König F,Anglmayer M, Rausch-Fan X, Gille G, Rausch WD, Lucas T, Sperr W, Schedle A. Cytotoxic effects of packable and nonpackable dental composites. Dent Mater.2003 Jul;19(5):382-92.

25. Manhart J, Kunzelmann KH, Chen HY,Hickel R. Mechanical properties of new composite restorative materials. J Jiomed Mater Res. 2000;53(4):353-61.

26. Thomé T, Steagall W Jr, Tachibana A, Braga SR, Turbino ML Influence of the distance of the curing light source and composite shade on hardness of two composites. J Appl Oral Sci. 2007 Dec;15(6):486-91.

27. Ergun G,EgilmezF,Cekic-Nagas I. The cytotoxicity of resin composites cured with three light curing units at different curing distances. Med Oral Patol Oral Cir Bucal. 2011Mar 1;16(2):e252-9. doi:10.4317/medoral.16.e252.

28. Harorli OT, Bayindir YZ, Altunkaynak Z, Tatar A.Cytotoxic effects of TEGDMA on THP-1cells in vitro. Med Oral Patol Oral Cir Bucal. 2009 Sep 1;14(9):e489-93.

29. Moharamzadeh K, NoortRV, Brook IM, Scutt AM. Cytotoxicity of resin monomers on human gingival fibroblasts and HaCaT keratinocytes. Dent Mater. 2007 Jan;23(1):40-4. Epub 2006 Jan 19.

30. Franz A, Konradsson K, Konig F, Van Dijken JW,Schedle A. Cytotoxicity of a calcium aluminate cement in comparison with other dental cements and resin-based materials. Acta Odontol Scand. 2006 Feb;64(1):1-8.

31. Jerg A, Schulz SD, Tomakidi P, Hellwig E, Polydorou O. Modulation of gingival cell response towards dental composites. Dent Mater.2018 Mar;34(3):412-426. doi: 10.1016/j.dental.2017.11.025. Epub 2018 Jan3.

32. Polydorou 0, König A, Hellwig E, Kümmerer K. Long-term release of monomers from modern dental-composite materials. Eur J Oral Sci. 2009 Feb;117(1):68-75. doi: 10.1111/.1.1600-0722.2008.00594.x.

33. Manojlovik D, Radisic M, Vasilievik T,Zivkovik S, Lausevic M, Miletic V. Monomer elution from nanohybrid and ormocer-based composites cured with different light sources. DentMater.2011 Apr;27(4):371-8. doi:10.1016/j.dental.2010.11.017. Epub 2010Dec 18.

34. Susila Anand V, Balasubramanian V. Effect of resin chemistry on depth of cure and cytotoxicity of dental resin composites. Mater Sci Eng B. 2014 Feb;181:33-8. doi:10.1016/.jmseb.2013.09.007.

35. Ferracane JL, Condon JR. Rate of elution of leachable components from composite. Dent Mater. 1990 0ct;6(4):282-7.doi: 10.1016/S0109-5641(05)800120.

\section{Numan Aydin PhD}

(Corresponding address)

Address: University of Health Sciences, Gulhane Faculty of Dentistry, Department

of Restorative Dental Treatment, Etlik 06018 Ankara, Turkey

Date submitted: 2019 0ct 14

E-mail: dt_numan@hotmail.com 